\title{
Vegetation Structure and Regeneration Status of the Western Escarpment of the Rift Valley of the Gamo Zone, Southern Ethiopia
}

\author{
Temesgen Dingamo ${ }^{1 *}$, Serekebirhan Takele ${ }^{2}$, Zerihun Woldu ${ }^{3}$, Sebsebe Demissew $^{3}$ \\ ${ }^{1}$ Biodiversity Conservation and Research Center, College of Natural Science, Arba Minch University, Arba Minch, Ethiopia \\ ${ }^{2}$ Department of Biology, College of Natural Science, Arba Minch University, Arba Minch, Ethiopia \\ ${ }^{3}$ Department of Plant Biology \& Biodiversity Management, College of Natural \& Computational Sciences, Addis Ababa University, \\ Addis Ababa, Ethiopia \\ Email: *temesgendingamo@yahoo.com
}

How to cite this paper: Dingamo, T., Takele, S., Woldu, Z. and Demissew, S. (2022) Vegetation Structure and Regeneration Status of the Western Escarpment of the Rift Valley of the Gamo Zone, Southern Ethiopia. Open Journal of Ecology, 12, 94-111.

https://doi.org/10.4236/oje.2022.121006

Received: December 11, 2021

Accepted: January 25, 2022

Published: January 28, 2022

Copyright $\odot 2022$ by author(s) and Scientific Research Publishing Inc. This work is licensed under the Creative Commons Attribution International License (CC BY 4.0).

http://creativecommons.org/licenses/by/4.0/

\begin{abstract}
Understanding the structure and regeneration of forest resources contributes to identifying the elements of diversity, endemism, threatened and endangered species. This study was conducted in the western escarpment of the Rift valley of the Gamo Zone, Southern Ethiopia. The main objective was to investigate structure and regeneration status of the study area. A systematic sampling method was used to collect vegetation data from a total 102 quadrats, each $20 \times 20 \mathrm{~m}\left(400 \mathrm{~m}^{2}\right)$ and five $1 \times 1 \mathrm{~m}\left(1 \mathrm{~m}^{2}\right)$ sub-quadrats were established at the four corners and at the centre for sapling and seedling estimation. Tree and shrub species were listed; Height $(\mathrm{H} \geq 1.5 \mathrm{~m})$ and $\mathrm{DBH} \geq 2$ $\mathrm{cm}$ were measured and recorded. R-statically software and Microsoft Excel were used to record and analyse the data. A total of 126 plant species belonging to 43 families and 90 genera were identified. The most dominant families were Fabaceae, followed by Anacardiaceae and Euphorbiaceae. Most frequent species were Euclea divinorum (84.3\%), followed by Rhus natalensis (83.3\%), Terminalia brownii $(74.5 \%)$. DBH class $\leq 5 \mathrm{~cm}$ had highest density $(63.6 \%)$ and $\mathrm{DBH} \geq 25.1 \mathrm{~cm}$ had the lowest density $(0.87 \%)$. Three population patterns have been observed; inverted J, J-shaped and irregular shaped. $93 \%$ of species had IVI values b/n $1-4,65 \%$ of species IVI values $<1 \%$ and $7 \%$ of species had IVI values $\geq$ 5.28. Pappea capensis, Combretum molle, Terminalia brownii, Euclea divinorum had highest IVI values. In the vertical stratification, lower story was $91.3 \%$ of the individuals. Only a few species contributed to the high density of saplings (440.2/ha) and seedlings (825.49/ha) while most had very little or no saplings and seedlings at all. Thus, in order to revert the current forest structure and regeneration to the previous natural state, it is
\end{abstract}


considered important to minimize the influence of the human interference, grazing and raising awareness to surrounding community.

\section{Keywords}

Importance Value Index, Regeneration, Seedling/Sapling, Vegetation Structure

\section{Introduction}

Diverse physiographic, altitudinal, climatic, and edaphic differences enable Ethiopia to have various vegetation types ranging from alpine to desert plant communities [1] [2] [3] [4] and the species in that provide economic, sociocultural, and environmental benefits. As a result, Ethiopia is endowed with rich flora and fauna and that makes the country an important centre of diversity and endemism [5] [6] [7] [8]. It has the fifth highest biodiversity in Africa [9].

Forests in East Africa accounted for $21 \%$ of the forest area in Africa. However, the annual rate of deforestation in the region has increased from $0.7 \%$ during the period 1981-1990 (FAO, 1993) to 1\% between 1999-2000 [10]. The annual deforestation rate in Ethiopia exceeds $0.8 \%$ [11].

Forest coverage in Ethiopia has been threatened by habitat conversion, loss, and fragmentation that occurred over the past many years [12] [13] [14]. The forest covered about $35 \%$ of the land area in the early $19^{\text {th }}$ century [15]; $16 \%$ in the 1950 's, reduced to $3.6 \%$, in 1980 and to $2.7 \%$ in 1989 [16] [17]. The remaining forest resources of the country are found in areas in the western and south western parts of Ethiopia, mainly not unduly affected by human settlements as well as human disturbance [12].

The threats those conversions of natural forests into grazing lands, woodlands, and wetlands to agriculture and settlement in Ethiopia [18] [19]. The overall change in forest cover leads to forest degradation, habitat loss and fragmentation, which in turn leads to changes in forest structures that affect the sustainability of the forest in the escarpment [2] [18].

The study area is facing rapid deforestation and degradation of forest resources [20] due to population pressure that forced the conversion of forest land into other forms (agriculture, settlement, etc.). There was no previous study in the area documenting the structure and regeneration status. Hence in order to address the following research objectives were provided: 1) to identify vegetation structure of woody species in the study area; 2) to assess the regeneration status of woody species in the study area.

\section{Materials and Methods}

\subsection{Description of the Study Area}

The study was carried out in the western escarpment of the rift valley of the Gamo Zone, Southern Ethiopia (Figure 1). Topographically, the study area consists 


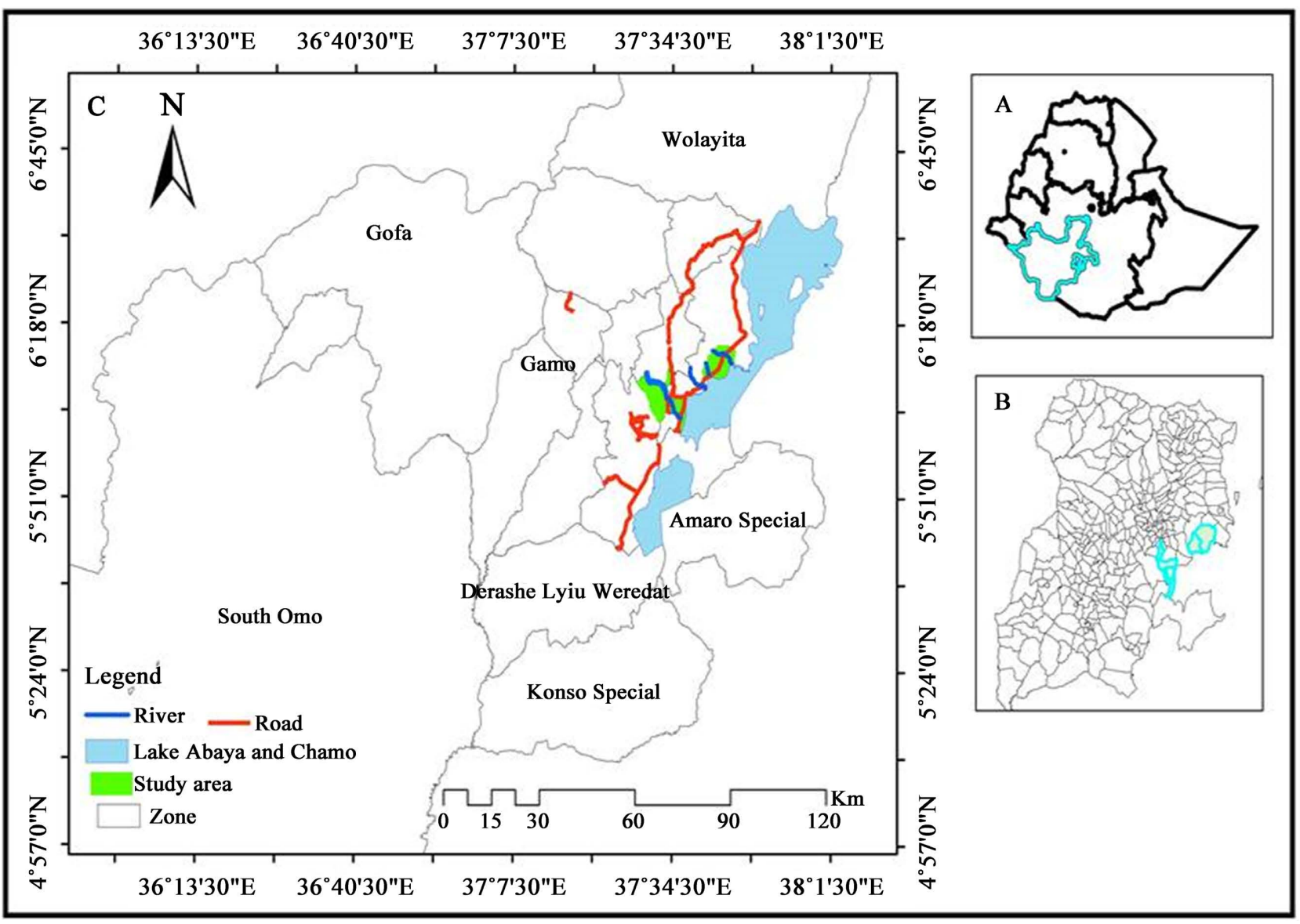

Figure 1. Location map for the study area $(\mathrm{A}=$ Ethio-Region, $\mathrm{B}=$ Gamo Zone, $\mathrm{C}=$ Study area (surrounded Zone, Lakes Abaya and Chamo, Rivers and Roads all weathered)).

of plains and hill sides of the Gamo mountain ridge between $6^{\circ} 05^{\prime} \mathrm{N}$ to $6^{\circ} 12^{\prime} \mathrm{N}$ and $37^{\circ} 33^{\prime} \mathrm{E}$ to $37^{\circ} 39^{\prime} \mathrm{E}$. The elevation of the area ranging from $1168 \mathrm{~m}$ to $2535 \mathrm{~m}$ a.s.l and the slope of the forest ranges between 0 to 32 degrees.

The Central Statistical Authority [21] report shows that the total size of the population in the study area is $1,825,027$ of which 857,266 are males and 967,761 are females.

[1] (2010) described the vegetation of the study area as Combretum-Terminalia woodland and wooded grassland, Acacia-Commiphora woodland and bushland and Dry evergreen Afromonatne forest. The most common tree species in the area are Terminalia brownii, Combretum molle, Ziziphus mauritiana, Pappea capensis, Cadaba farinosa, Vachellia spp. and Senegalia spp. Balanites aegyptiaca, Commiphora abyssinica, Rhus natalensis, Olea europaea subsp. cuspidata, Psydrax schimperiana, Acokanthera schimperi and Juniperus procera.

The geology of the Western Rift-valley Escarpment is mainly quaternary volcanic alluvial deposits and lacustrine clay [22]. The soil types are classified into sand, sandy clay loam, sandy loam and loam sandy.

The climate of the study area

The climate of the study area and the surrounding is characterized by a pro- 
longed period of dry months and bimodal rainfall pattern which can barely support a vegetation cover that can provide the desired ecological functions and ecosystem services. The maximum and minimum mean annual rainfall for 20 years between 1990-2019 was $1141.1 \mathrm{~mm}$ and $491.8 \mathrm{~mm}$, respectively. The maximum and minimum mean annual temperature was $33.6^{\circ} \mathrm{C}$ and $15^{\circ} \mathrm{C}$, respectively (Figure 2). The prolonged dry periods between two short wet periods imply a high rate of evapotranspiration and desiccation of the soil leading to the predominance of deciduous dry forest.

\subsection{Sampling Design and Vegetation Data Collection}

A systematic sampling technique was used to collect vegetation data to ensure full coverage of environmental variation and habitat heterogeneity following [23]. One hundred and two main quadrats (plots) were selected to determine the various parameters of the vegetation in the study area.

Thirteen transects parallel to each other and approximately $500 \mathrm{~m}$ apart from each other were laid along the altitudinal gradient in the western escarpment of the Rift valley. The sampling quadrats were placed at a regular interval of $200 \mathrm{~m}$ between each other beginning from the lowest altitude of the escarpment and extending to the highest altitude. One hundred and two main quadrats, each 20 $\mathrm{m} \times 20 \mathrm{~m}\left(400 \mathrm{~m}^{2}\right)$ quadrats were used. A Modified-Whittaker nested vegetation sampling method [24] was used to collect species richness, cover-abundance, population, height and diameter at breast height $(\mathrm{DBH})$ of tree species at multiple spatial scales, using $1 \mathrm{~m}^{2}$, and $(5 \times 5 \mathrm{~m}) 25 \mathrm{~m}^{2}$ within a $20 \mathrm{~m} \times 20 \mathrm{~m}(400$ $\mathrm{m}^{2}$ ) main quadrat. Data on trees and shrubs were collected in the main quadrats. Data on seedlings and saplings were collected in $25 \mathrm{~m}^{2}$ sub-quadrats. The sub-quadrats were placed at the four corners and one at the center of the main quadrat.

Height was measured using a Suunto Clinometer and Compass, and DBH was measured using a caliper. Individuals with $\mathrm{DBH} \geq 2 \mathrm{~cm}$ and height $\geq 1.5 \mathrm{~m}$ were

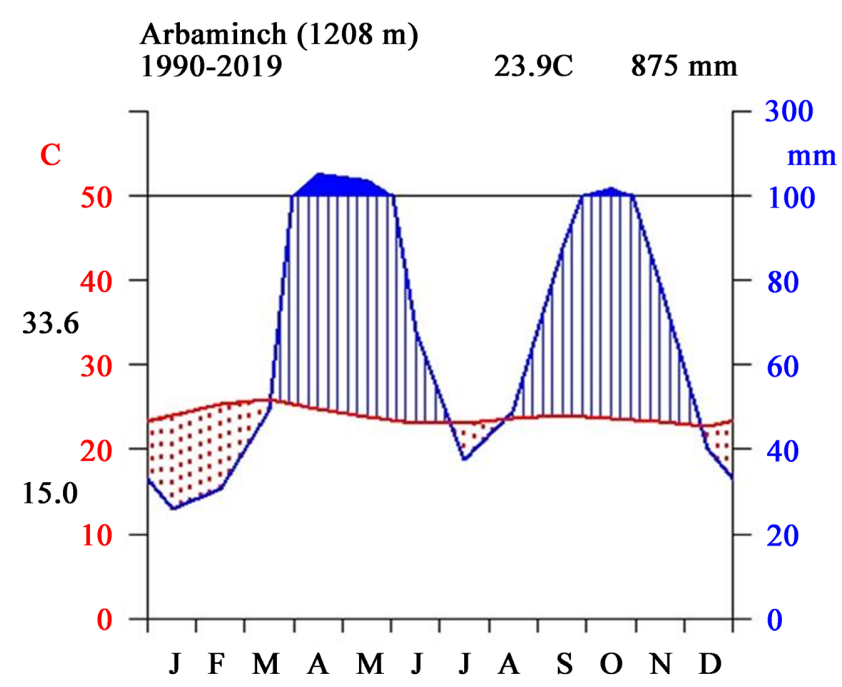

Figure 2. Annual mean maximum and minimum and rainfall in mm (1990-2019). 
considered as trees/shrubs. Individuals with DBH between $0.5 \mathrm{~cm}$ and $2 \mathrm{~cm}$ and height between $0.5 \mathrm{~m}$ and $1.5 \mathrm{~m}$ were considered as saplings while those with root collar diameter $\leq 0.5 \mathrm{~cm}$ and height $\leq 0.5 \mathrm{~m}$ were considered as seedlings.

In each quadrat anthropogenic disturbance factors including grazing and disturbance (marks of cutting, fuelwood collection, fire, and charcoal production) were recorded. Impact of grazing intensity class was estimated following [25] [26], as 3 = heavy; 2 = moderate; $1=$ lightly; and $0=$ not grazed, while the state human activities were estimated following [27] [28] using modified 0 - 3 subjective scale to determine the degree of the impacts of fuelwood collection, charcoal production, selective tree cutting and fire. The sum of all scores for each quadrat was determined following an overall ranking of human disturbances index in each quadrat following [29], (2003).

Geographical location, altitude, slope and aspect (the direction of the slope of the sample quadrat faces) were recorded using a Garmin GPS 72 ( $\pm 3 \mathrm{~m}$ accuracy). Slope (\%) was recorded using a Suunto Clinometer and Compass. Aspect was coded following [30] as: North $=0$; East $=2$; South $=4$; West $=2.5$ and NW $=1.3$.

Voucher specimens of each species encountered in the quadrats and subquadrats were collected, pressed and identified in the National Herbarium of Ethiopia, Addis Ababa University and deposited in the Herbarium of Arba Minch University. Taxonomic nomenclature follows Volumes $2-8$ of the Flora of Ethiopia and Eritrea [31]-[36].

\subsection{Data Analysis}

\section{Diversity}

Species diversity and evenness of the clusters identified were calculated using the Shannon-Wiener diversity index. The Shannon-wiener diversity index is commonly used to characterize species diversity in a community. ShannonWiener's index accounts for both the abundance and evenness of the species present. The proportion of species $i$ relative to the total number of species $\left(p_{i}\right)$ is calculated and then multiplied by the natural logarithm of this proportion $\left(\ln p_{i}\right)$. The resulting product is summed across species, and multiplied by -1 compute using Equation (1).

$$
H^{\prime}=\sum_{i}^{S} p_{i} \ln \left(p_{i}\right)
$$

where $p_{i}$ is the proportion of individuals that belong to species $i$ and $S$ is the number of species in the sample.

Shannon's equitability ( $/$ Shannon's equitability $\left(E_{H}\right)$ can be calculated by dividing $H$ by $H_{\max }$ (here $H_{\max }=\ln S$ ). Equitability assumes a value between 0 and 1 with 1 being complete evenness calculated by Equation (2).

$$
\text { Equitability }(J)=\frac{H}{H_{\max }}=\frac{H}{\ln S}
$$

\section{Vegetation Structural}

Structural data were analysed using Microsoft excel, R statistical software and 
performed on the bases of density, $\mathrm{DBH}$, height, frequency, basal area per hectare and IVI were calculated Equation (3)-(10).

Density is a total number of individuals of each species in all the quadrats is divided by the total number of quadrats studied. Density is calculated by the equation:

$$
\text { Density }=\frac{\text { Total number of individuals of a species in all quadrats }}{\text { Total number of quadrats studied }}
$$

Frequency is calculated by the equation:

$$
\text { Frequency }(\%)=\frac{\text { Number of quadrats in which the species occured }}{\text { Total number of quadrats studied }} \times 100
$$

Abundance is represented by the equation:

$$
\text { Abundance }=\frac{\text { Total number of individuals of a species in all quadrats }}{\text { Total number of quadrats in which the species occurred }}
$$

Basal area (BA): It is the cross-sectional area of tree stems at breast height (1.3 $\mathrm{m}$ above ground level). Generally, it is a measure of dominance, which refers to the degree of coverage of species that occupies at ground level [23].

$$
\mathrm{BA}=\frac{\frac{1}{4} \pi d^{2}}{4}
$$

where: $\mathrm{BA}=$ Basal Area in $\mathrm{m}^{2} \mathrm{ha}^{-1}, d=$ diameter at breast height $(\mathrm{m})$, and $\pi=3.14$.

Dominance $(\mathrm{DO})=$ total cover or basal area of species A/area sampled.

Importance Value Index is used to determine the overall importance of each species in the community structure. In calculating this index, the percentage values of the relative frequency, relative density and relative dominance are summed up together and this value is designated as the Importance Value Index or IVI of the species [23].

$$
\text { IVI = Relative density + Relative frequency + Relative dominance }
$$

$$
\begin{gathered}
\text { Relative frequency }=\frac{\text { Number of quadrats in which species occurred }}{\text { Total number of quadrats occupied by all species }} * 100 \\
\text { Relative density }=\frac{\text { Total number of individuals of the species }}{\text { Sum of all individuals of all species }} * 100 \\
\text { Relative Dominance }=\frac{\text { Dominance of given species }}{\text { Total dominance of all species }} * 100
\end{gathered}
$$

\section{Vertical Structure}

The vertical stratification of the tree in the study area was examined using IUFRO classification scheme [37]. According to this scheme, tree with height above $2 / 3 \mathrm{~m}$ top height represent upper story, tree with height between $1 / 3$ and $2 / 3$ represent middle story and tree with height $<1 / 3$ represent lower story.

\section{Regeneration status}

The regeneration status of some tree species was determined based on the population size of seedlings and saplings following [38] (1987) as:

1) good regeneration if seedlings > saplings > adults; 
2) fair regeneration if seedlings $>$ or $\leq$ saplings $\leq$ adults;

3) poor regeneration if the species survives only in sapling stage, but no seedlings (saplings may be or $=$ adults).

4) no regeneration if a species is present only in adult form.

5) new regeneration if the species has no adults but only seedlings or saplings.

\section{Results and Discussion}

\subsection{Floristic Composition}

A total of 126 species belonging to 90 genera and 43 families were encountered. The floristic composition of the vegetation at the family level includes 10 major families such as Fabaceae (15.87\%) Anacardiaceae (5.6\%), Euphorbiaceae and Capparidaceae (5.6\%) Rubiaceae and Tiliaceae represented (4\% each) Acanthaceae, Asteraceae, Celastraceae and Combretaceae represented by 4 (3.2\% each) and 32 minor families represented by $0.8 \%-2.4 \%$ of the total species number. Trees, shrubs and herbs, climbers and lianas constituted 55.6\%, 26.2\%, 11.9\% herbs, $3.2 \%$ climbers and $3.2 \%$ respectively.

\subsection{Vegetation Structure}

\section{Frequency}

Based on the percentage frequency values, woody plant species were classified into five frequency classes: $\mathrm{A}=81-100$ (2), $\mathrm{B}=61-80$ (3), $\mathrm{C}=41-60$ (4), $\mathrm{D}=$ $21-40$ (16), $\mathrm{E}=0-20 \%$ (101). The most frequently distributed species in the escarpment forest was Euclea divinorum (84.3\%), followed by Rhus natalensis (83.3\%), Terminalia brownie (74.5\%), Combretum molle (71.6), Pappea capensis (62.8) and Dodonaea angustifolia (54.9) (Figure 3).

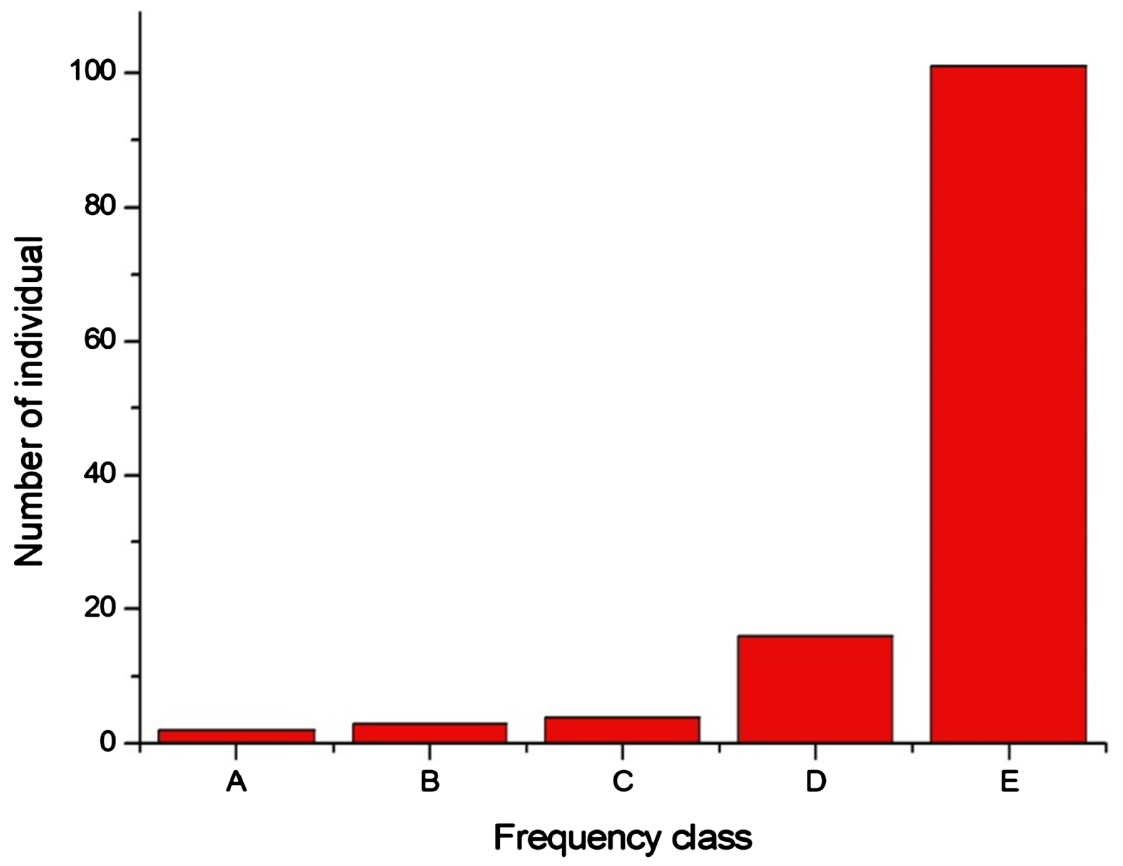

Figure 3. Distribution of species by Frequency class. 


\section{Basal area and Dominance}

Basal area is the total cross-sectional area of all stems in a stand measured at breast height and expressed as per unit of land area. The total basal area in the study area was $266.01 \mathrm{~m}^{2} \cdot \mathrm{ha}^{-1}$. The total basal area of stems in the study area is low compared to other sites in Ethiopia [39]. The basal area of the ten most important species in the study area was account for $65.64 \%$ of the total basal area (Table 1).

\section{DBH classes}

The DBH data of the woody species were categorized into seven classes $(\mathrm{DBH} 1=0-5 \mathrm{~cm} ; \mathrm{DBH} 2=5.1-10 \mathrm{~cm} ; \mathrm{DBH} 3=10.1-15 \mathrm{~cm} ; \mathrm{DBH} 4=15.1-20$ $\mathrm{cm}$; DBH5 $=20.1-25 \mathrm{~cm}$; DBH6 $=25.1-30 \mathrm{~cm}$ and DBH7 $\geq 30.1 \mathrm{~cm}$ ). The general pattern of the DBH class distribution in the study area was inverted J shape (Figure 4).

Table 1. Basal area and density of the of the ten most important species in the study area

\begin{tabular}{lccccc}
\hline & Scientific Name & Basal area $\mathrm{m}^{2} \cdot \mathrm{ha}^{-1}$ & Rank & Density & Rank \\
\hline 1 & Pappea capensis & 36.86 & 1 & 44.36 & 9 \\
2 & Combretum molle & 30.30 & 2 & 76.96 & 6 \\
3 & Terminalii brownii & 25.88 & 3 & 89.95 & 4 \\
4 & Euclea divinorum & 24.09 & 4 & 185.78 & 1 \\
5 & Mystroxylon aethiopicum & 14.08 & 5 & 28.68 & 12 \\
6 & Olea europaea subsp. cuspidata & 12.83 & 6 & 72.55 & 7 \\
7 & Senegalia mellifera & 9.89 & 7 & 22.55 & 14 \\
8 & Balanites aegyptiaca & 9.52 & 8 & 4.90 & 41 \\
9 & Sclerocarya birrea & 5.60 & 9 & 7.35 & 36 \\
10 & Cadaba farinosa & 5.58 & 10 & 21.57 & 15 \\
\hline
\end{tabular}

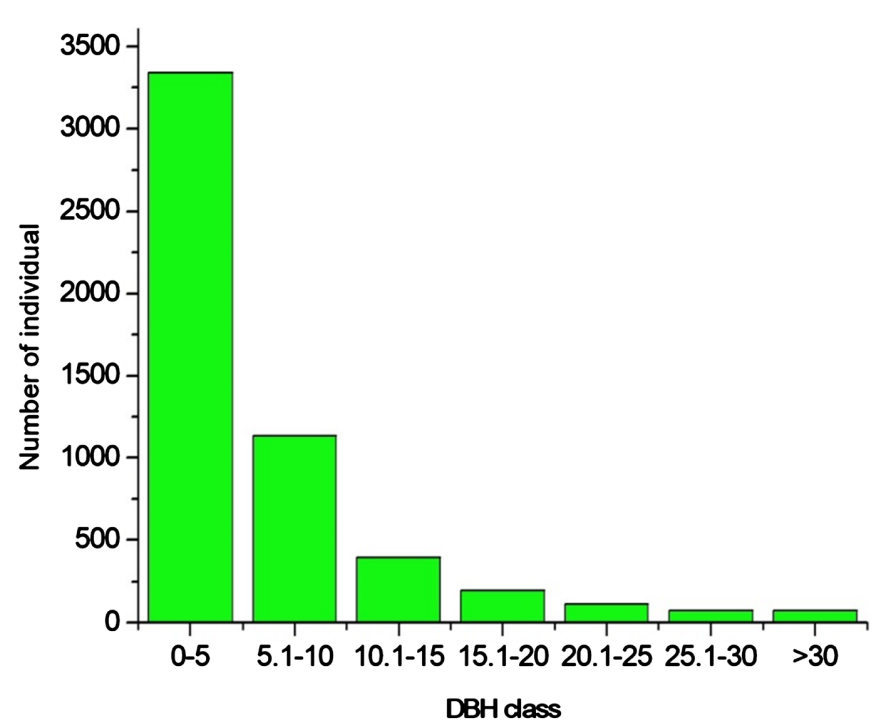

Figure 4. DBH class distribution in the study area. 
Stems with $\mathrm{DBH} \leq 5 \mathrm{~cm}$ constituted the highest density $\left(6462.04 / \mathrm{ha}^{-1}\right.$ or $62.5 \%$ ) while those with $\mathrm{DBH} \geq 25 \mathrm{~cm}$ had the lowest density with $88.4 / \mathrm{ha}^{-1}$ (5.1\%) (Table 1). Three different patterns (Inverted J-shape, J-shape, and Irregular shape) were manifested by nine species with high basal area in the five community types (Figure 5). Among the ten species with the highest DBH Pappea capensis, Combretum molle, Terminalii brownii, Euclea divinorum, Olea europaea subsp. cuspidata, Senegalia mellifera manifested inverted J shape. Balanites aegyptiaca manifested J shape and Scrocarya birrea manifested irregular shape.

\section{Height distribution}

The height classes were classified into six categories $\left(\mathrm{H}_{1}=0-2.5 \mathrm{~m} ; \mathrm{H}_{2}=2.6\right.$ $5.0 \mathrm{~m} ; \mathrm{H}_{3}=5.1-7.5 \mathrm{~m} ; \mathrm{H}_{4}=7.6-10 \mathrm{~m} ; \mathrm{H}_{5}=10.1-12.5 \mathrm{~m}$ and $\left.\mathrm{H}_{6} \geq 12.6 \mathrm{~m}\right)$. The height distribution of the species in the study area is suggestive of scattered trees with short to medium-high trees breaking the uniformity of the low sclerophyllous vegetation cover (Figure 6).

\section{Importance Value Index}

Importance Value Index (IVI) analysis of all woody species distribution of the study areas were grouped in to four IVI classes based on their total IVI values $\left(\mathrm{IVI}_{1} \leq 1, \mathrm{IVI}_{2}\right.$ between $1.1-5 ; \mathrm{IVI}_{3}$ between $5.1-10$ and $\left.\mathrm{IVI}_{4} \geq 10.1\right)$. The results revealed that $\mathrm{IVI}_{1} \leq 1$ had $65 \%$ of total species and IVI $\geq 5.1$ had contained only 8 species and contributed 6.34\%. Species with high IVI value Pappea capensis (17.73), Combretum molle (15.75), Terminalia brownie (14.23), Euclea divinorum (14.18). On the other hand, about eighty two (82) species each has less than 1\% IVI values, for example, Abutilon figarianum (0.17), Polyscias fulva (0.17), Calpurnia aurea (0.11) and Aloe calidophila (0.11).
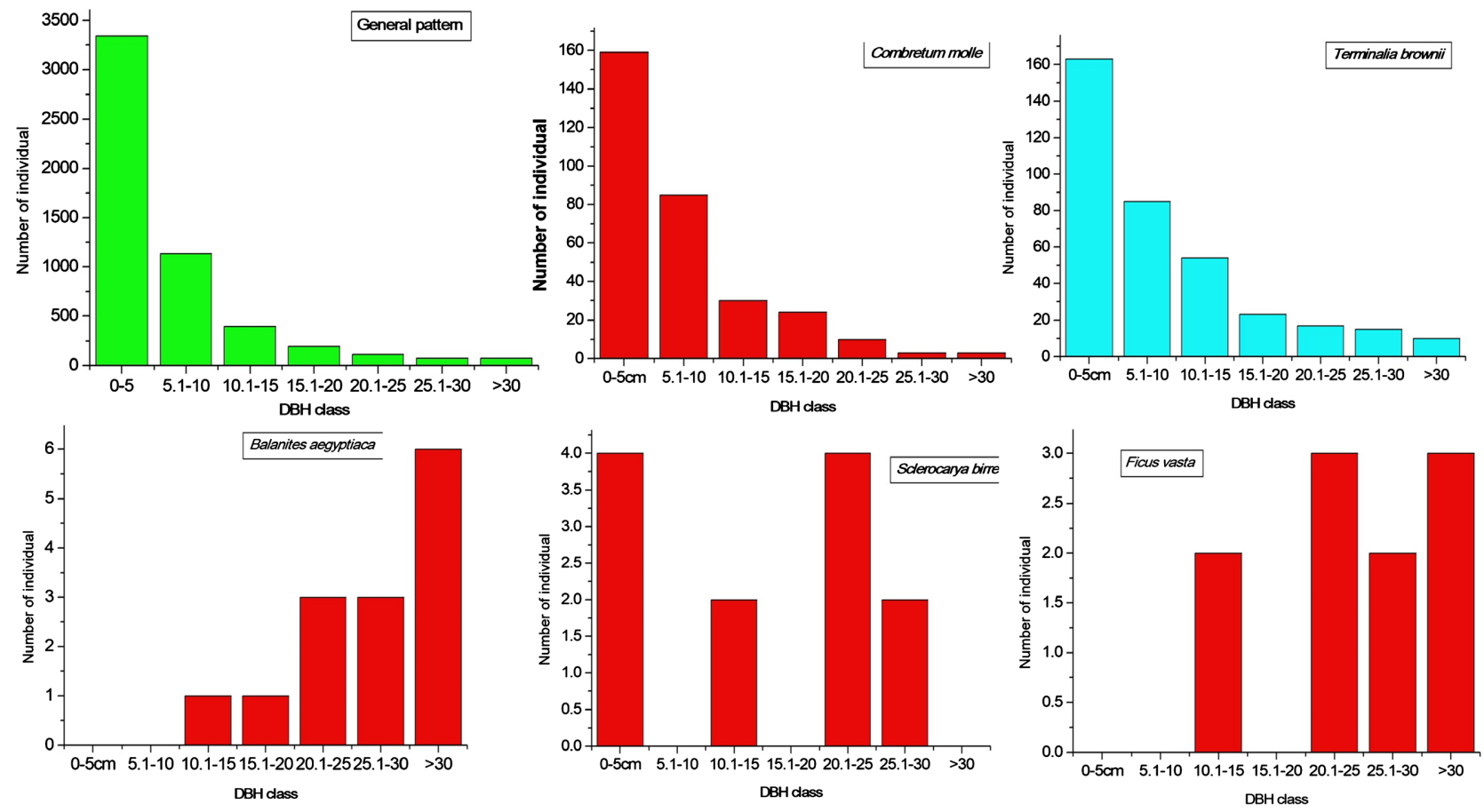

Figure 5. Selected six species DBH class distribution. 


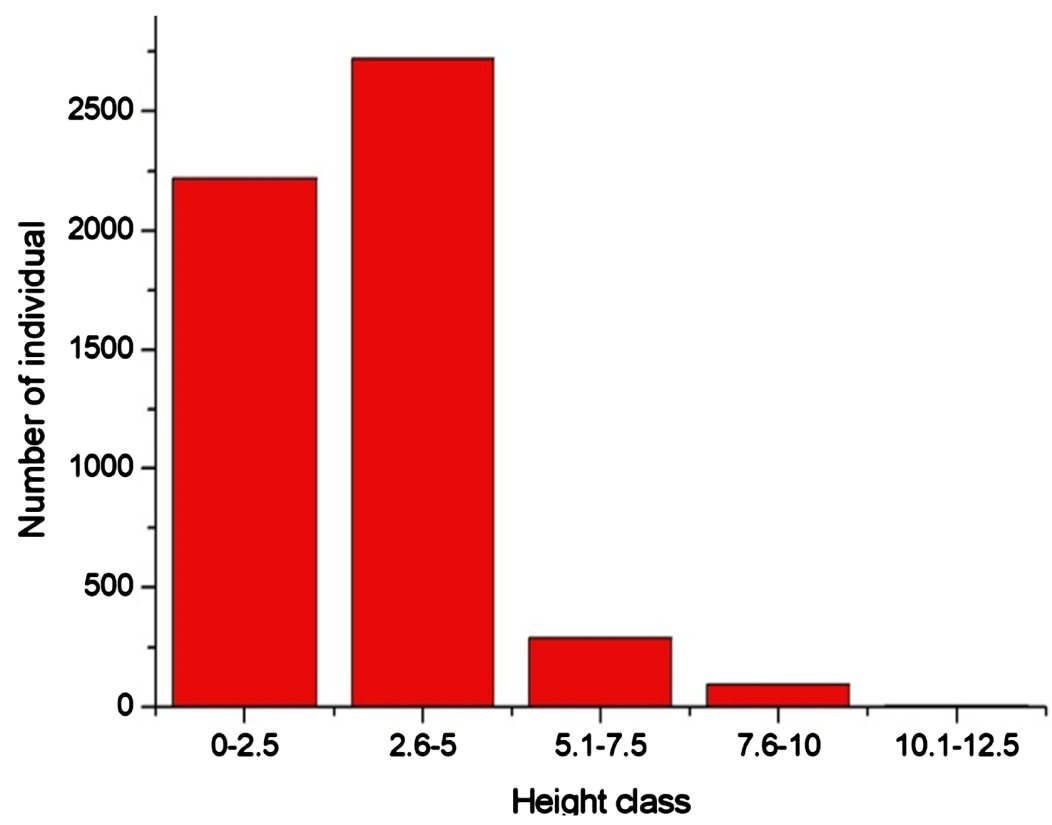

Figure 6. Height distribution of the study area.

Table 2. Density and species number in the western escarpment.

\begin{tabular}{ccccccc}
\hline Stratum & Height $(\mathrm{m})$ & Density (steam/ha) & $\%$ & No species & $\%$ & ratio \\
\hline Lower & $2-5$ & 4131 & 91.3 & 68 & 54 & $60: 1$ \\
Middle & $5.1-10$ & 388 & 8.5 & 49 & 38.9 & $7: 1$ \\
Upper & $\geq 10.1$ & 9 & 0.2 & 9 & 7.1 & $1: 1$ \\
\hline
\end{tabular}

\section{Vertical stratification of the western escarpment}

The vertical stratification of the trees and shrubs in the study area represent mainly lower story which is $91.3 \%$ of the individuals followed by the middle (8.5\%) and upper (0.2\%) (Table 2).

\section{Regeneration status}

The seedling and sapling stages were represented by 49 species belonging to 39 genera and 23 families in the study area. Only a few tree species in the study area had saplings and seedlings underneath them. The species with high sapling and seedling density include Terminalia brownie $\left(77.45 \mathrm{~m}^{2} \cdot \mathrm{ha}^{-1}\right)$, Olea europaea subsp. cuspidata $\left(48.78 \mathrm{~m}^{2} \mathrm{ha}\right)$, Pappea capensis $\left(41.2 \mathrm{~m}^{2} \cdot \mathrm{ha}^{-1}\right)$, Mystroxylon aethiopicum $\left(29.7 \mathrm{~m}^{2} \cdot \mathrm{ha}^{-1}\right)$ and Dichrostachys cinerea $\left(17.9 \mathrm{~m}^{2} \cdot \mathrm{ha}^{-1}\right)$. The total mature tree, sapling and seedling density in the study area is shown in Figure 7. The result shows that not all seedlings are recruited to maturity as a result of the constraints imposed by browsing, desiccation, and other biological, climatic, edaphic, and anthropogenic influences.

\section{Discussion}

Species in families Fabaceae and Anacardiaceae were the most frequently occurring species in the vegetation of the study area. Most species in the family Fabaceae and 


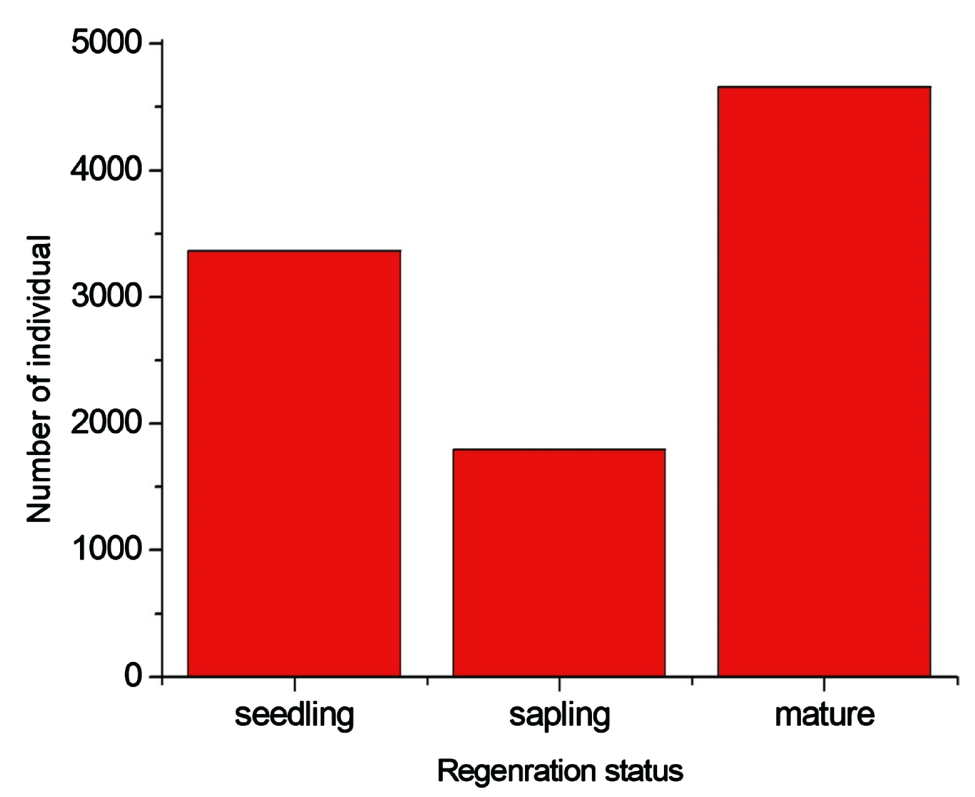

Figure 7. Regeneration status of the study area.

Asteraceae are drought-tolerant, deciduous, and well adapted to the climatic conditions of the ecological and agro-ecological zones of Ethiopia. Both these plant families are among the families with high species richness in the Flora of Ethiopia and Eritrea [40]. Fabaceae and Asteraceae show frequent occurrence in vegetation probably due to their efficient pollination and successful seed dispersal mechanisms that might help them to adapt to a wide range of ecological conditions [41].

The frequency gives an approximate indication of the homogeneity and heterogeneity of a stand. The escarpment forest has $80.15 \%$ of species in the lower frequency class $\mathrm{E}$, in the middle class (D) $12.69 \%$ of species presented and in the higher frequency classes (A, B and C) 7.14\% of species were presented. Two species belongs to the frequency class A; frequency class $\mathrm{B}, \mathrm{C}$ and $\mathrm{D}, 3,4$ and 16 species represented respectively. On the other hand, the lower frequency class (E) comprised 101 species. Based on the description of [37], the percentage frequency of the present study revealed high degree of floristic heterogeneity. This might be associated with a bimodal rainfall patterns and to reduced reproduction (that is, flower production, pollination and seed production).

The cumulative DBH class distribution of the western escarpment of the Rift valley showed that inverted J-shaped pattern. The lower density of DBH individuals $(\mathrm{DBH} \leq 5 \mathrm{~cm})$ has large proportion than large sized individuals $(\mathrm{DBH} \geq$ $25.1 \mathrm{~cm}$ ). These were showed that western escarpment of the Rift valley has high density, which indicated that there are more dominance of lower and medium sized DBH class. This might be associated with the selective cutting of species for fuel wood collection, local house building (hat house), charcoal production and others. Similar results were observed in [21] [42] [43] [44] [45].

Selected six species showed that three pattern of vegetation structure of the study area. The first pattern was inverted J-shape pattern, Combretum molle, 
Euclea divinorum, Ochna inermis, Olea europaea subsp. Cuspidata, Pappea capensis and Terminalia browni, this means high number of individuals in the lower DBH size classes and low number of individuals in the higher DBH size classes.

The second pattern was J-shape and displayed by Balanites aegyptiaca, with low number of individuals in the lower DBH size classes and high number of individuals in the higher DBH size classes. This might be species are harvested at an early growth stage by the local people for charcoal production, live fence and construction of houses. Several studies were reported in the different region of Ethiopia for [46] in the Sheko forest; [43] in the Hallideghie wildlife reserve; [47] Vegetation Ecosystem of Ethiopia; [44] in the boda dry evergreen Montana forest; [48] in the rangeland of Southeast Ethiopia and [49] in the Kimphe Forest.

Last but not least, Species, such as Scrocarya birrea showed relatively irregular-shape with irregular number of individuals in the different DBH classes. Those species which manifested irregular patterns indicate that stems of these species are harvested for various domestic uses at any stage as found fit for the purpose.

The height distribution of the study area is seems like inverted J-shaped. This shown that lower height class of large-sized individuals and the upper height classes a few number of individual. This implies that the western escarpment of the Rift valley presence of small number of adult trees for reproduction and clearing mature trees for different purposes such as house construction, charcoal production and expansion of agriculture and settlement. This agree with those of [43] [47] [50] [51] in the afromontane forests of Ethiopia, Vegetation Ecosystem of Ethiopia, Hallideghie wildlife reserve and Shello Giorgis dry Afromontane forest, respectively.

The result indicates that high IVI was attributed to few species. These species are those which are well adapted to the high pressure of disturbance, natural and environmental factors as well as the effect of local communities. In contrast to this idea, almost all species in this study showed variation in terms of their IVI, showing different ecological importance of each species in the escarpment forest. $6.34 \%$ Species were recorded IVI values between $5.1-10$ and $\geq 10.1,28.57 \%$ of species were recorded in IVI between $1.1-5$ and the rest of $65.08 \%$ species with IVI values $<1$. In our study, basal area analysis across individual species revealed that very few species had high dominance. A species having value of IVI $\geq 5.00$ can be considered dominant because of the relative ecological role it plays in the ecosystem [23]. As indicated in IUFRO classification scheme [37], IVI value is used for comparison of ecological significant of species in which high IVI values indicate that the species structure in the community is high.

The results revealed that the lower story was representing $91.3 \%$ of the individuals followed by the middle (8.5\%) and upper (0.2\%)). This type of distribution might be explained by the fact that species with overlapping size distributions can coexist as a result of differences in maximum attainable size. The 
presence of difference in tree height is one of the adaptive morphological bases for their high degree of floristic heterogeneity. This suggests that short species are likely to allocate more to radial growth, thereby acquiring the physical stability needed to survive in the western escarpment [37].

The composition, distribution and density of seedlings and saplings are an indicator for the future habitat conditions, geographical distribution, composition, successful regeneration and survival and growth within space and time [52] [53]. The density of saplings $\left(440.2 \mathrm{ha}^{-1}\right)$ and seedlings $\left(825.49 \mathrm{ha}^{-1}\right)$ were dominated by few species. 50 species (48.5\%) were not represented by both seedlings and saplings but, it was represented by mature individuals. On the other hand, 3 species (2.9\%) were no seedlings and/or saplings represented. Finding of this work shown seedlings were greater than that of sapling, but less than mature trees. Similar findings were also reported by [54] [55] [56] Ratios of seedlings to saplings $=1.88: 1$, seedlings to mature trees and shrubs $=0.72: 1$, saplings to mature trees and shrubs $=0.39: 1$. This indicated that less number of saplings was recorded than that of the seedling and mature trees and shrubs. Even though the density of seedlings which is greater than that of the saplings and less than mature trees and shrubs indicates as the vegetation is in a fair regeneration status, the density of saplings has not followed similar trend. Accordingly, the distribution pattern where the density of the mature trees and shrubs exceeded the total density of the seedling and saplings shows that the regeneration status of the studied vegetation is at a fair state [38].The density of seedlings obtained from the study area was less than the report made by [57] [58] [59] [60]. This could be due to the high exposure of the escarpment for grazing, selective tree cutting, agriculture expansion and settlement. Those species without saplings and seedlings are vulnerable to local extinction in the escarpment and if conservation measures are not introduced shortly, a loss of species diversity and the associated components of biodiversity could be inescapable.

\section{Conclusions}

The results of the study indicated that the study in the western escarpment of the Rift valley had relatively high woody species diversity and was dominated by small sized tree and shrub species in secondary stage of development, indicating that the western escarpment of the Rift valley was heavily exploited and affected in the previous periods and now going on pressure.

Fabaceae is the most dominant family in terms of species number represented by 20 (15.87\%). DBH class $\leq 5 \mathrm{~cm}$ had highest density (63.63\%) and $\mathrm{DBH} \geq$ $25.1 \mathrm{~cm}$ had the lowest density $(0.87 \%)$. The density of woody species decreases with increasing DBH and height, indicating the predominance of small-sized individuals in the area.

Three population patterns have been observed; inverted J, J-shaped and irregular shaped. Species with high IVI values were recorded like Pappea capensis (17.73), Combretum molle (15.75), Terminalia brownie (14.23), Euclea divi- 
norum (14.18). In the study area three vertical structures were classified and lower story was represented by $91.3 \%$ of the individuals followed by the middle (8.5\%) and upper (0.2\%).

Regeneration analyses of woody species were dominated by few species and most of the tree species were without seedling and sapling stage. However, some tree species are represented by all stages (seedling, sapling, and mature trees).

\section{Conflicts of Interest}

The authors declare no conflicts of interest regarding the publication of this paper.

\section{References}

[1] Friis, I., Demissew, S. and van Breugel, P. (2010) Atlas of the Potential Vegetation of Ethiopia. The Royal Danish Academy of Sciences and Letters, Copenhagen.

[2] Demissew, S. and Friis, I. (2009) Nature Vegetation of the Flora Area. In: Hedberg, I., Friis, I. and Persson, E., Eds., Flora of Ethiopia and Eritrea Eritrea, Vol. 8, National Herbarium, Addis Abeba University, Addis Abeba, 27-32.

[3] Gebre Kirstos, S. (1984) An Ecological Study of the Vegetation on the Eastern Escarpment of Eritrea, Ethiopia. Addis Ababa.

[4] White, F. (1983) The Vegetation of Africa: A Discriptive Memoir to Accompany the 56 UNESCO/AETFAT/UNESCO Vegetation Map of Africa. Natural Resource Research 20, United Nations Educational, Scientific and Cultural Organization, Paris.

[5] Temesgen, F., Warkineh, B. and Ababa, A. (2018) Biodiversity Status \& Conservation Challenges of Protected Areas of Ethiopia: Awash \& Nechsar National Parks in Focus. Journal of Natural Sciences Research, 8, 46-61.

[6] Amberber, M., Argaw, M., Feyisa, G.L. and Degefa, S. (2020) Status, Approaches, and Challenges of Ecosystem Services Exploration in Ethiopia: A Systematic Review. Chinese Journal of Population, Resources and Environment, 18, 201-213. https://doi.org/10.1016/j.cjpre.2019.07.001

[7] Asefa, M., Cao, M., He, Y., Mekonnen, E., Song, X. and Yang, J. (2020) Ethiopian Vegetation Types, Climate and Topography. Plant Divers, 42, 302-311. https://doi.org/10.1016/j.pld.2020.04.004

[8] Nyssen, J., Poesen, J., Moeyersons, J., Deckers, J., Haile, M. and Lang, A. (2004) Human Impact on the Environment in the Ethiopian and Eritrean Highlands-A State of the Art. Earth-Science Reviews, 64, 273-320. https://doi.org/10.1016/S0012-8252(03)00078-3

[9] Wood, A.P. and Stahl, M. (1997) Ethiopia: National Conservation Strategy, Phase I Report. International Union for Conservation of Nature, Addis Ababa.

[10] Food and Agriculture Organization of the United Nations (2001) World Wide Agroclimatic Data Base. CD-ROM FAO Clim 2. Food and Agriculture Organization of the United Nations, Rome.

[11] Food and Agriculture Organization of the United Nations (2010) Global Forest Resource Assessment. Food and Agriculture Organization of the United Nations, Rome.

[12] Dessie, G. and Kleman, J. (2007) Pattern and Magnitude of Deforestation in the South Central Rift Valley Region of Ethiopia. Mountain Research and Development, 27, 162-168. https://doi.org/10.1659/mrd.0730 
[13] Husen, A., Mishra, V.K., Semwal, K. and Kumar, D. (2012) Biodiversity Status in Ethiopia and Challenges. Environmental Pollution and Biodiversity, 1, 31-79.

[14] Tolera, M., Asfaw, Z., Lemenih, M. and Karltun, E. (2008) Woody Species Diversity in a Changing Landscape in the South-Central Highlands of Ethiopia. Agriculture, Ecosystems \& Environment, 128, 52-58. https://doi.org/10.1016/j.agee.2008.05.001

[15] European Federation for Agricultural Recycling (EFAR) (1994) Ethiopian Forestry Action Program: The Challenge for Development. Final Report, Volume II, Ministry of Natural Resources Development and Environmental Projection, Addis Ababa. European Federation for Agricultural Recycling, Addis Ababa.

[16] Craft, C. (2002) Methods for Evaluating Wetland Condition \#16: Vegetation-Based Indicators of Wetland Nutrient Enrichment. Office of Water, U.S. Environmental Protection Agency, Washington DC, EPA-822-R-02-020.

[17] Food and Agriculture Organization of the United Nations (2008) Forests, Deforestation and Forest Degradation: Most frequently Asked Questions. FAO Advisory Committee on Paper and Wood Products, Bakubung. Food and Agriculture Organization of the United Nations, South Africa.

[18] National Biodiversity Strategies and Action Plans (NBSAPs) (2005) National Biodiversity Strategy and Action Plan. National Biodiversity Strategies and Action Plans, Addis Ababa.

[19] Awas, T., Bekele, T. and Demissew, S. (2001) An Ecological Study of the Vegetation of Gambella Region, Southwestern Ethiopia. SINET: Ethiopian Journal of Science, 24, 213-228. https://doi.org/10.4314/sinet.v24i2.18187

[20] Wana, D. and Woldu, Z. (2006) Vegetation of Chencha Highlands in Southern Ethiopia. SINET: Ethiopian Journal of Science, 28, 109-118. https://doi.org/10.4314/sinet.v28i2.18247

[21] CSA Group (2019) Summary and Statistical Report of the Population and Housing Census. CSA Group, Addis Ababa.

[22] Mateos, A., Jiménez, A. and Ríos-Insua, S. (2003) Solving Dominance and Potential Optimality in Imprecise Multi-Attribute Additive Problems. Reliability Engineering and System Safety, 79, 253-262. https://doi.org/10.1016/S0951-8320(02)00237-5

[23] Coker, P. and Kent, M. (2001) Vegetation Description and Analysis: A Practical Approach Review by: Petr Smilauer. Folia Geobotanica, 36.

[24] Stohlgren, A.T.J., Falkner, M.B., Schell, L.D., Vegetatio, S. and Apr, N. (2012) A Modified-Whittaker Nested Vegetation Sampling Method Reviewed Work(s): A Modified-Whittaker Nested Vegetation Sampling Method. Vegetatio, 117, 113-121. https://doi.org/10.1007/BF00045503

[25] Hines, J.E., Latour, P.B., Squires-Taylor, C. and Moore, S. (2011) The Effects on Lowland Habitat in the Banks Island Bird Sanctuary Number 1, Northwest Territories, by the Growing Colony of Lesser Snow Geese (Chen Caerulescens caerulescens). Environment Canada Occasional Paper No. 118, Environment Canada, Canadian Wildlife Service, Edmonton, 8-26.

[26] Zerihun I. and Backéus, W. (1991) The Shrub Land Vegetation in Western Shewa, Ethiopia and Its Possible Recovery. Journal of Vegetation Science, 2, 73-180. https://doi.org/10.2307/3235949

[27] Kidane, L., Nemomissa, S. and Woldu, Z. (2016) The Effects of Disturbance on the Population Structure and Regeneration Potential of Five Dominant Woody Species-In Hugumburda-Gratkhassu National Forest Priority Area, North-Eastern Ethiopia. African Journal of Ecology, 54, 20-28. https://doi.org/10.1111/aje.12254 
[28] Yeshitela, K. and Bekele, T. (2002) Plant Community Analysis and Ecology of Afromontane and Transitional Rainforest Vegetation of Southwestern Ethiopia. SINET: Ethiopian Journal of Science, 25, 155-175. https://doi.org/10.4314/sinet.v25i2.18078

[29] Venkateswaran, R. and Parthasarathy, N. (2003) Tropical Dry Evergreen Forests on the Coromandel Coast of India: Structure, Composition and Human Disturbance. Ecotropica, 9, 45-58.

[30] Woldu, Z., Feoli, E. and Nigatu, L. (1989) Partitioning an Elevation Gradient of Vegetation from Southeastern Ethiopia by Probabilistic Methods. Vegetatio, 81, 189-198. https://doi.org/10.1007/BF00045524

[31] Edwards, S.D., Edwards, S., Tadesse, M., Demissew, S. and Phillips, S. (1995) Flora of Ethiopia and Eritrea. Vol. 2, Addis Ababa University, Addis Ababa; Uppsala University, Uppsala.

[32] Sebseb. D. and Edwards, H.I. (1997) Flora of Ethiopia and Eritrea: Hydrocharitaceae-Arecaceae. Vol. 6, Addis Ababa University, Addis Ababa; Uppsala University, Uppsala.

[33] Hedberg, I., Kelbessa, E., Edwards, S. and Demissew, S. (2006) Flora of Ethiopia and Eritrea: Gentianaceae Cyclocheilaceae. Vol.5, Addis Ababa University, Addis Ababa; Uppsala University, Uppsala.

[34] Hedberg, I., Edwards, S. and Nemomissa, S. (2003) Flora of Ethiopia and Eritrea: Magnoliaceae Flacourtiaceae. Vol. 4, Addis Ababa University, Addis Ababa; Uppsala University, Uppsala

[35] Schmid, R. (1998) Review of Flora of Ethiopia and Eritrea. Vol. 6. Hydrocharitaceae to Arecaceae; Flora of Ethiopia and Eritrea. Vol. 2, Pt. 2. Canellaceae to Euphorbiaceae; Flora of Ethiopia and Eritrea. Vol. 7. Poaceae (Gramineae); Flora of Ethiopia. Vol. 3. Pittosporaceae to Araliaceae; Some Endemic Plants of Ethiopia, by S. Edwards, S. Demissew, I. Hedberg, M. Tadesse, I. Hedberg, \& S. Phillips. Taxon, 47, 779-780. https://doi.org/10.2307/1223616

[36] Hedberg, I., Friis, I. and Edwards, S. (Eds.) (2004) Flora of Ethiopia and Eritrea: Asteraceae (Compositae). Vol. 4, Part 2, The National Herbarium, Addis Ababa.

[37] Lamprecht, H. (1989) Silvic Culture in the Tropics. Tropical Forest Ecosystems and Their Tree Species Possibilities and Methods for Their Long-Term Utilization. TZ-Verlag, Roßdorf.

[38] Khan, M.L., Rai, J.P.N. and Tripathi, R.S. (1987) Population Structure of Some Tree Species in Disturbed and Protected Subtropical Forests of North-East India. Acta Oecologica/Oecologia Appl, 8, 247-255.

[39] Tadese, S., Soromessa, T., Bekele, T. and Gebeyehu, G. (2021) Woody Species Composition, Vegetation Structure, and Regeneration Status of Majang Forest Biosphere Reserves in Southwestern Ethiopia. International Journal of Forestry Research, 2021, Article ID: 5534930. https://doi.org/10.1155/2021/5534930

[40] Kelbessa, E. and Demissew, S. (2014) Diversity of Vascular Plant Taxa of the Flora of Ethiopia and Eritrea. Ethiopian Journal of Biological Sciences, 13, 37-45.

[41] Kelbessa, E. and Soromessa, T. (2011) Interfaces of Regeneration, Structure, Diversity and Uses of Some Plant Species in Bonga Forest: A Reservoir for Wild Coffee Gene Pool. SINET: Ethiopian Journal of Science, 31, 121-134. https://doi.org/10.4314/sinet.v31i2.66565

[42] Boz, G. and Maryo, M. (2020) Woody Species Diversity and Vegetation Structure of Wurg Forest, Southwest Ethiopia. International Journal of Forestry Research $s$, 2020, Article ID: 8823990. https://doi.org/10.1155/2020/8823990 
[43] Ahmed, E., Ali, S. and Addisu, A. (2017) Structure and Regeneration Status of Woody Plants in the Hallideghie Wildlife Reserve, North East Ethiopia. International Journal of Biodiversity and Conservation, 9, 200-211. https://doi.org/10.5897/IJBC2017.1085

[44] Fikadu, E., Melesse, M. and Wendawek, A. (2014) Floristic Composition, Diversity and Vegetation Structure of Woody Plant Communities in Boda Dry Evergreen Montane Forest, West Showa, Ethiopia. International Journal of Biodiversity and Conservation, 6, 382-391. https://doi.org/10.5897/IJBC2014.0703

[45] Senbeta, F. and Teketay, D. (2001) Regeneration of Indigenous Woody Species under the Canopies of Tree Plantations in Central Ethiopia. Tropical Ecology, 42, 175 185.

[46] Senbeta, F., Woldemariam, T., Demissew, S. and Denich, M. (2009) Floristic Diversity and Composition of Sheko Forest, Southwest Ethiopia. Ethiopian Journal of Biological Sciences, 6, 11-42. https://doi.org/10.4314/ejbs.v6i1.39038

[47] Lemessa, D. (2017) Woody Species Composition in Relation to Spatial and Environmental Gradients in Acacia-Commiphora Vegetation Ecosystem of Ethiopia. International Journal of Natural Resource Ecology and Management, 2, 53-59. https://doi.org/10.11648/j.ijnrem.20170203.12

[48] Abate, T., Ebro, A. and Nigatu, L. (2012) Evaluation of Woody Vegetation in the Rangeland of Southeast Ethiopia. International Research Journal of Agricultural Science and Soil Science, 2, 113-126.

[49] Senbeta, F. and Teketay, D. (2003) Diversity, Community Types and Population Structure of Woody Plants in Kimphe Forest, a Virgin Nature Reserve in Southern Ethiopia. Ethiopian Journal of Biological Sciences, 2, 169-187.

[50] Senbeta, F., Schmitt, C., Woldemariam, T. and Denich, M. (2014) Plant Diversity, Vegetation Structure and Relationship between Plant Communities and Environmental Variables in the Afromontane Forests of Ethiopia. SINET: Ethiopian Journal of Science, 37, 113-130.

[51] Ayalew, T., Merawi, E. and Alemu, S. (2019) Woody Plant Species Diversity of Shello Giorgis Dry Afromontane Forest, Farita District, West Amhara, Ethiopia. Biodivers. Ecology and Evolutionary Biology, 4, 60-71. https://doi.org/10.11648/j.eeb.20190404.13

[52] Khumbongmayum, A., Khan, M. and Tripathi, R. (2005) Ethnomedicinal Plants in the Sacred Groves of Manipur. Indian Journal of Traditional Knowledge, 4, 21-32.

[53] Good, N.F. and Good, R.E. (1972) Population Dynamics of Tree Seedlings and Saplings in a Mature Eastern Hardwood Forest. Bulletin of the Torrey Botanical Club, 99, 172-178. https://doi.org/10.2307/2484571

[54] Denu, D. (2007) Floristic Composition and Ecological Study of Bibita Forest (Gura Ferda), Southwest Ethiopia. MSc. Thesis, Addis Ababa University, Addis Ababa.

[55] Shibru, S. and Balcha, G. (2004) Composition, Structure and Regeneration Status of Woody Species in Dindin Natural Forest, Southeast Ethiopia: An Implication for Conservation. Ethiopian Journal of Biological Science, 3, 15-35.

[56] Dibaba, A., Soromessa, T., Kelbessa, E. and Tilahun, A. (2014) Diversity, Structure and Regeneration Status of the Woodland and Riverine Vegetation of Sire Beggo in Gololcha District, Eastern Ethiopia. Momona Ethiopian Journal of Science, 6, 70-96. https://doi.org/10.4314/mejs.v6i1.102416

[57] Tilahun, A. (2018) Vegetation Ecology and Carbon Stock of Wof-Washa Forest, North Vegetation Ecology and Carbon Stock of Wof-Washa Forest, North Shewa Zone, Amhara Region, Ethiopia (Thesis). Addis Ababa University, Addis Ababa. 
[58] Ahmedin, A. and Eliasb, E. (2020) Tree Species Composition, Structure and Regeneration Status in Munessa Natural Forest, South-Eastern Ethiopia. Eurasian Journal of Forest Science, 8, 21-39. https://doi.org/10.31195/ejejfs.622956

[59] Berhanu, A., Demissew, S., Woldu, Z. and Didita, M. (2017) Woody Species Composition and Structure of Kuandisha Afromontane Forest Fragment in NorthWestern Ethiopia. Journal of Forestry Research, 28, 343-355.

https://doi.org/10.1007/s11676-016-0329-8

[60] Fisaha, G., Hundera, K. and Dalle, G. (2013) Woody Plants' Diversity, Structural Analysis and Regeneration Status of Wof Washa Natural Forest, North-East Ethiopia. African Journal of Ecology, 51, 599-608. https://doi.org/10.1111/aje.12071 